\title{
Evaluation of the Antimicrobial Effect of the Extracts of the Pods of Piliostigma thonningii (Schumach.) Milne-Redh. (Fabaceae)
}

\author{
Memory Makosa, Simbarashe Sithole $(\mathbb{D}$, and Stanley Mukanganyama $\mathbb{i}$ \\ Department of Biochemistry, University of Zimbabwe, Mt. Pleasant, Harare, Zimbabwe \\ Correspondence should be addressed to Stanley Mukanganyama; smukanganyama@medic.uz.ac.zw
}

Received 29 October 2020; Revised 12 January 2021; Accepted 30 January 2021; Published 13 February 2021

Academic Editor: Heng Yen Khong

Copyright (C) 2021 Memory Makosa et al. This is an open access article distributed under the Creative Commons Attribution License, which permits unrestricted use, distribution, and reproduction in any medium, provided the original work is properly cited.

\begin{abstract}
Plants have been used traditionally by people in treating and the management of diseases since time immemorial. Traditional medicines including the herbal medicines are used for primary healthcare in some domains in almost every country. Approximately $80 \%$ of the population in developing coutries depend on plants as their source of medicine for combating diseases. New and effective antimicrobial agents that have novel mechanism of actions are required. Piliostigma thonningii (Schumach.) Milne-Redh. is a species of flowering plants in the legume family, Fabaceae. Different parts of the P. thonningii plants such as the roots, leaves, seeds, and fruits have been used in treating wounds, heart pain, and gingivitis and as cough remedy. This study focused on determining the antimicrobial properties found in the pods of $P$. thonningii. The sample was prepared by grinding the dried pods into a fine powder. Successive extraction and extraction with 1:1 DCM: methanol was used. The antimicrobial assay was carried out using the broth microdilution and MTT assay. The microorganism used for the tests was Pseudomonas aeruginosa, Candida krusei and Mycobacterium smegmatis. The most potent extract was then used to determine its effect on microbial cell membrane integrity. The results showed that methanol extract had the highest percentage yield of $5 \%$. The extract with the highest antimicrobial effects was ethanol extract with the $100 \mu \mathrm{g} / \mathrm{mL}$ concentration inhibiting the growth of cells to $26 \%, 87 \%$, and $90 \%$ for $P$. aeruginosa, M. smegmatis, and C. krusei, respectively. The ethanol extracts caused significant leakage of proteins in these microorganisms. In conclusion, the pods of $P$. thonningii contain phytochemicals with antimicrobial properties. The pods of the plant can be a source of phytochemicals that can serve as sources of lead compounds with antimicrobial effects. One of the mechanisms of action of these phytochemicals is via membrane-damaging effects on microbes.
\end{abstract}

\section{Introduction}

Plants have long been used in the prevention, diagnosis, and treatment of different physical as well as mental illnesses. About $50 \%$ of current drugs are derived either directly or indirectly from plants, with approximately $80 \%$ of the population in developing countries relying exclusively on plants as sources of medicines [1]. Several studies have shown that medicinal plants are composed of bioactive compounds with proven efficacy as the basic raw material of drugs [2]. In Zimbabwe, there are more than 5000 species of plants of which only $10 \%$ of themhave been used for medicinal properties. Traditional medicine is still regarded as the cheapest and most accessible source of treatment against diseases in many communities in Zimbabwe [3].

An antimicrobial agent is defined as the agent that inhibits the growth or destroy microorganism [4]. Secondary metabolites have contributed to the antimicrobial potency of natural products against several diseases. The therapeutic effects of medicinal plants showed physiological action on the human body. Hence, people use them for the general maintenance of health [5]. Medicinal plants have frequently been used as raw materials for the extraction of bioactive constituents for the production of different drugs [6]. In a study to explore and record plants used by the traditional healers of South Africa, $P$. thonningii roots, bark, and leaves were found to be used 
to treat loss of appetite, or for alleviating stomach problems as well as haematochezia [7].

Piliostigma thonningii Schum. is a leguminous plant that belongs to the family Fabaceae and Caesalpinioideae subfamily which comprises 133 genera [8]. The crude extract of $P$. thonningii has been reported to possess antilipidemic, antibacterial, antihelminthic, and anti-inflammatory activities [2]. The presence of bioactive compounds such as flavonoids, tannins, kaurane diterpenes, alkaloids, carbohydrates, saponins, terpenes, and volatile oils has shown the potential of inhibiting the growth of pathogens [9]. Most of the previous studies on the plant $P$. thonningii were on leaves, with these studies demonstrating anti-inflammatory, analgesic, and toxic effects of the leaf extracts [10]. In a recent study, it was shown that aqueous, and methanolic stem bark extracts of $P$. thonningii, possessed analgesic and anti-inflammatory activities [11]. Antifungal screening on the aqueous and ethanolic extracts of $P$. thonningii leaves has shown them to have antifungal effects on Colletotrichum musae and Sclerotium rolfsii [12]. P. thonningii stem bark $60 \%$ methanolic extract has been reported to possess antibacterial activity against Bacillus subtilis, Corynebacterium pyogenes, Escherichia coli, Proteus vulgaris, Shigella dysenteriae, and Staphylococcus aureus [13].

Considerable information exists on the phytochemicals present in $P$. thonningii. In an investigation by Ighodaro et al. [14], they found that the aqueous and ethanol leaf extracts of the plant contained alkaloids, saponins, flavonoids, and tannins. In the same study, the extracts when tested for their antibacterial as well as antifungal activity showed effective inhibition of growth of human pathogenic microbes [14]. Moriasi et al. [15] qualitatively screened for the phytochemicals of the aqueous and methanolic stem bark extracts of $P$. thonningii and observed the presence of cardenolide glycosides, coumarins, phenols, steroids, saponins, and flavonoids.

Candida albicans, Candida glabrata, Candida tropicalis, Candida parapsilosis, and Candida krusei are five Candida species that cause $92 \%$ of cases of candidemia [16]. Mycobacterium smegmatis was discovered firstly to be a human pathogen in 1986 by Vonmoos [17]. From then, many cases of mycobacterial infections have been reported of which about $56-76 \%$ are of skin or soft-tissue infections. $P$. aeruginosacauses nosocomial infection in hospitalised patients and community-acquired infections. $P$. aeruginosa has been reported to be the second organism amongst others causing ventilator-associated pneumonia, catheter-associated urinary tract infections, wound infections in severe burn patients, and septicaemia [18]. In many developing as well as developed countries, there is indiscriminate use of antimicrobials that has led to the development of microbial resistance problems [19]. The rise of antimicrobial resistance had led to high cost, long period, and failure of treatment often leading to the death of patients. In an effort to stem the cost of producing as well as the comparatively high adverse effects of synthetic drugs, studies are being undertaken into the search for new antimicrobial substances from natural sources [20].
The pods of $P$. thonningii have not been investigated the antimicrobial potency, unlike other different parts which include leaves, stem, and roots. This study focused on determination of the antimicrobial properties found in the pods of $P$. thonningii. The extracts of the pods are tested against three types of microbial cells: $P$. aeruginosa, C. krusei, and $M$. smegmatis to determine the antimicrobial potency.

\section{Materials}

2.1. Chemicals and Reagents. All the chemicals and reagents used were obtained from Sigma-Aldrich Chemical Co. (Darmstadt, Germany). All solvents used were of analytical reagent grade; these were acetone, methanol, n-hexane, ethanol, dichloromethane, 3-(4,5-dimethylthiazolyl)-2,5diphenyltetrazolium bromide (MTT), potassium hydroxide $(\mathrm{KOH})$, and dimethyl sulfoxide (DMSO). The pods of Piliostigma thonningii were obtained from Norton, a town located in Mashonaland West Province of Zimbabwe $\left(17^{\circ} 53^{\prime} 0^{\prime \prime}\right.$ south, $30^{\circ} 42^{\prime} 0^{\prime \prime}$ east). The pods were identified and authenticated at the National Herbarium and Botanical Gardens at Harare by a taxonomist Mr. Christopher Chapano.

2.2. Bacterial Strain and Plant Material. The clinical strain of $P$. aeruginosa used during the tests was acquired from Parirenyatwa Hospital (Department of Medical Microbiology, College of Health Sciences, Harare, Zimbabwe). M. smegmatis $155 \mathrm{mc}^{2}$ laboratory strain was obtained from the Department of Clinical Laboratory Sciences, University of Cape Town. C. krusei was obtained from the Department of Biological Science at the University of Botswana.

\subsection{Extraction of Phytochemicals with Differential Solvents.} The pods of $P$. thonningii were dried for 3 days at $40^{\circ} \mathrm{C}$ in an oven. The dried pods were ground using pestle and mortar until it was a fine-powdered. The powder of the pods was sieved to remove unwanted fragments. The powder was placed in a container and stored at room temperature conditions. Two methods used for extraction were total extraction and serial exhaustive extraction. A mixture of solvents, methanol and dichloromethane $(1: 1)$, was used in the total extraction. A 50-gram mass of the powder was measured and placed in a 1-litre beaker followed by addition of $200 \mathrm{~mL}$ of the solvent. The mixture was left for overnight to allow for the extraction of phytochemicals. The same procedure was also carried out on serial exhaustive extraction. The solvents used were of varied polarity and ranged from nonpolar to polar. The order of the solvents was hexane, dichloromethane, acetone, ethyl acetate, ethanol, methanol, and water. After an overnight period, the extracts were filtered using cotton in the first round to remove debris. It was followed by the use of Whatman No. 1 filter paper for further filtration. The solvents were then dried in $50 \mathrm{~mL}$ centrifuge tubes on a fan until they are dried. The dried extracts were measured to obtain their mass. Eight extracts were obtained and further used for the antimicrobial assay. 
2.4. Screening for Antimicrobial Activity. All the microorganisms were grown from solid into the broth. The cells were cultured by aliquoting $20 \mu \mathrm{L}$ of media of the organism under study into $50 \mathrm{~mL}$ centrifuge tubes and inoculating the media with microbe inoculum. The cells were standardized using a 0.5 McFarland standard. The cells were then diluted to $2 \times 10^{6} \mathrm{CFU} / \mathrm{mL}$. The extracts were dissolved by measuring $0.004 \mathrm{~g}$ in $1 \mathrm{~mL}$ of DMSO and $0.002 \mathrm{~g}$ of the drug was dissolved in $1 \mathrm{~mL}$ DMSO. This was followed by serial dilutions which started from the highest concentration to the lowest concentration. For the highest concentration, $9.5 \mathrm{~mL}$ of media was added to $0.5 \mathrm{~mL}$ of the extracts and only $2.5 \mathrm{~mL}$ was transferred out from every tube upon dilutions. The concentration prepared were $6.3 \mu \mathrm{g} / \mathrm{mL}, 12.5 \mu \mathrm{g} / \mathrm{mL}, 25 \mu \mathrm{g} /$ $\mathrm{mL}, 50 \mu \mathrm{g} / \mathrm{mL}$, and $100 \mu \mathrm{g} / \mathrm{mL}$. The procedure was carried out on all the solvent extracts which include hexane, acetone, DCM, ethyl acetate, ethanol, methanol, water, and total extract of DCM:Methanol (1:1) extract. Standard antimicrobial agents were prepared in a DMSO: media $(0.5: 9.5 \mathrm{~mL})$ solution. This was done for the rifampicin, ciprofloxacin, and miconazole for the positive control. After serial dilutions, the solutions were plated on the 96-well plate. After 20-hour incubation at $37^{\circ} \mathrm{C}$ in an incubator (Lab Companion IS 300, Jeio Tech, Korea) of microorganisms and test samples, the cell viability was determined using MTT solution. In each well, $20 \mu \mathrm{L}$ of the solution was dispensed into the well. The plate was further incubated for 2 hours at $37^{\circ} \mathrm{C}$ in the incubator and the density of viable cells was determined spectrophotometrically at $590 \mathrm{~nm}$ in a Genios Pro microplate reader (Tecan Group Ltd., Grodig, Austria).

\subsection{Determination of the Effects of Extracts on Membrane} Integrity. In order to determine the effect of $P$. thonningii extracts on the bacterial and fungal membranes, the method of Fouda et al. [21] was used. The method determines the amount of proteins that leak from the organisms after exposure to membrane permeabilizing agents. The protein leakage assay was carried out by growing the microorganism under the test samples at $50 \mu \mathrm{g} / \mathrm{mL}, 100 \mu \mathrm{g} / \mathrm{mL}$, and $200 \mu \mathrm{g} / \mathrm{mL}$. Five tubes were labelled according to the respective concentration of the extract and the controls. This same procedure was carried out for all the three types of microorganisms used in this study. For positive control of C. krusei, miconazole was used. For M. smegmatis, $0.1 \%$ SDS was used. Lastly, for $P$. aeruginosa, ampicillin was used. For the $50 \mu \mathrm{g} / \mathrm{mL}$ test sample tube, the following constituents were added, $750 \mu \mathrm{L}$ of ethanol extract and $5250 \mu \mathrm{L}$ of a cell. For $100 \mu \mathrm{g} / \mathrm{mL}, 1500 \mu \mathrm{L}$ ethanol extract and $4500 \mu \mathrm{L}$ cells were added. Lastly, for $200 \mu \mathrm{g} /$ $\mathrm{mL}$ of ethanol extract, there was $2000 \mu \mathrm{L}$ of extract and $4000 \mu \mathrm{L}$ of the cells was added. The test with the positive control contained $600 \mu \mathrm{L}$ of a test sample and $5400 \mu \mathrm{L}$ of media. The negative control tube had $6000 \mu \mathrm{L}$ of cells in media. All the five tubes were placed for 2 hours at $37^{\circ} \mathrm{C}$ in an incubator (Lab Companion IS 300, Jeio Tech, Korea).

2.6. Statistical Analysis. Statistical analysis was done using the one-way analysis of variance (ANOVA) test. Further analysis of the results was carried out along with Dunnett's multiple comparison posttest to compare all mean values to the mean value of a control column for each test. Values with $p$ values $<0.05$ at $95 \%$ confidence intervals were considered to be statistically significant. GraphPad Prism $6^{\circledR}$ (Version 6.0, GraphPad Software Inc, San Diego, United States of America) software was used for all graphical and statistical analyses.

\section{Results and Discussion}

Microorganisms such as $P$. aeruginosa, $M$. smegmatis, and C. krusei have been shown to the cause of nosocomial infections which are acquired in a hospital during the periods of staying. An example of infection is candidemia caused by C. krusei which have shown an increasing incidence in nosocomial infections [22]. C. krusei has become resistant to fluconazole. The mortality ranges from infections by these organisms range between $36 \%$ and $63 \%$ [23]. P. aeruginosa, M. smegmatis, and C. krusei have displayed a mechanism to resist the available antimicrobial agents. This has led to the search for new and effective alternative medicines that can reduce these effects imposed by these pathogens. Traditionally, $P$. thonningii has been used for the treatment of ailments, which include bilharzia, wounds, and bleeding wounds [2]. This study focused on investigating the antimicrobial effects of the extracts of $P$. thonningii pods to establish the scientific basis for the traditional uses of the plant for treating microbial infections.

3.1. Antimicrobial Effects of the Extracts. The extracts of the pods of $P$. thonningii against $P$. aeruginosa, $M$. smegmatis, and C. kruseiwere shown to be effective and comparable to the antimicrobial effects of the reference drugs. The more polar solvents were shown to be effective against all the three human pathogenic microbes.

3.1.1. The Antimycobacterial Effects of the Extracts against M. smegmatis. A total of eight extracts were tested against $M$. smegmatis to determine the antimycobacterial properties found in the pods of $P$. thonningii. A typical profile of the results obtained for the microbroth dilution assay for M. smegmatis is shown in Figure 1. The results were plotted as graphs of cell density at $590 \mathrm{~nm}$ against extract concentration as shown in Figures 2 and 3. Whilst there was a reduction in the growth as shown by the hexane and methanol extracts, the other extracts were infective in reducing the growth of M. smegmatis. No MIC was observed for all the 8 extracts against $M$. smegmatis. The ethanol extract $(100 \mu \mathrm{g} / \mathrm{mL})$ had the highest activity with a percentage growth inhibition of $87 \%$ and followed by the methanol extract $(100 \mu \mathrm{g} / \mathrm{mL})$ which had a percentage growth inhibition of $78 \%$. The water extract showed no activity (Figure 3 ).

M. smegmatis has been used as a model organism for the analysis of drugs used for treating tuberculosis. $M$. smegmatis shared about 2000 homology genes with M. tuberculosis [24]. Tuberculosis has greatly caused high death rate around the world and it was estimated that one- 


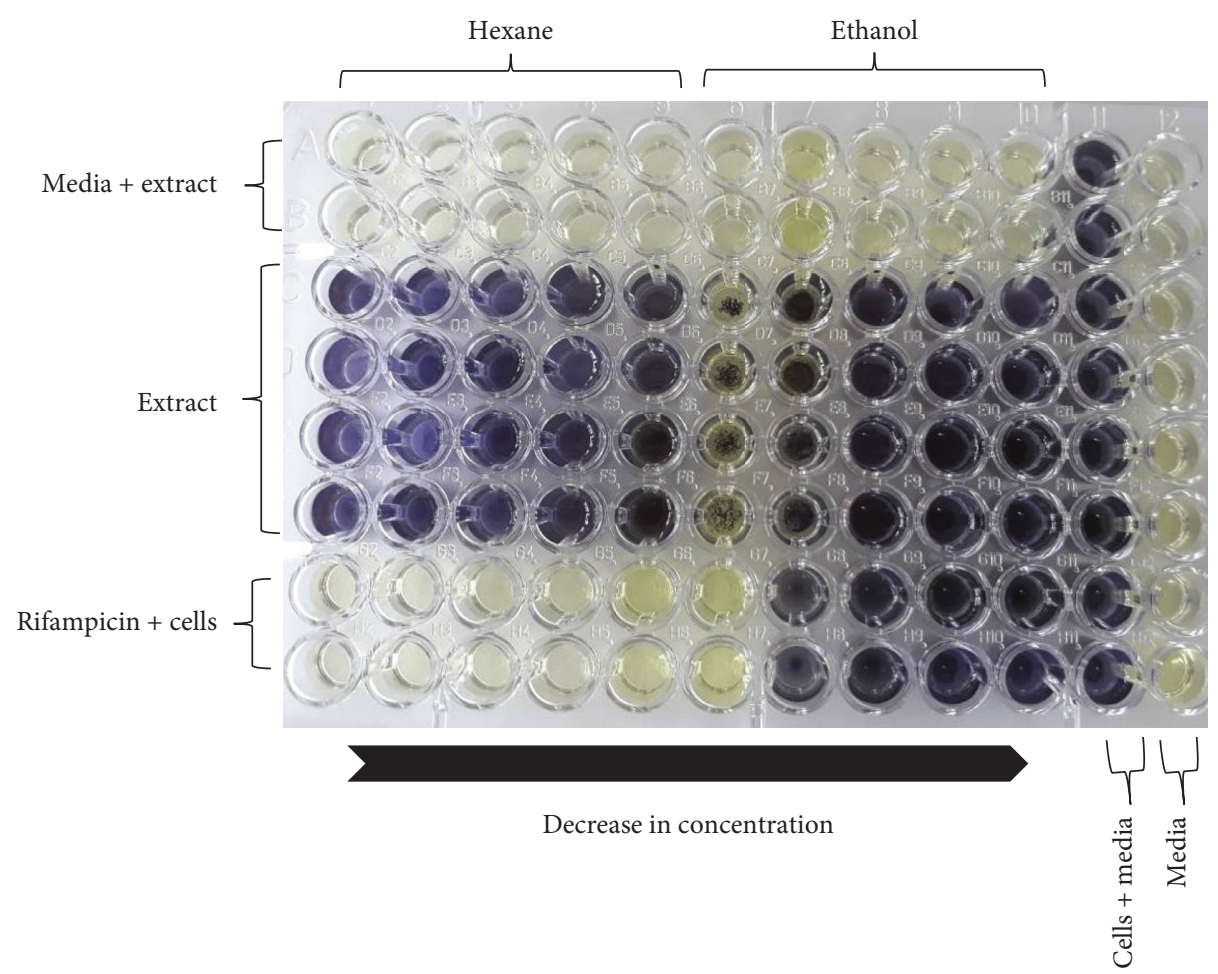

Figure 1: A typical microbroth dilution assay showing MTT results after subculture of $M$. smegmatis with control drug rifampicin and hexane and ethanol pod extracts of $P$. thonningii. Viable M. smegmatis cells reduced yellow MTT dye to blue. This indicated that there was no inhibition of M. smegmatis in wells with blue colour. Column 11 represents cells only well (positive control). Column 12 containing media only remained yellow. Thus, no contamination of media occurred. The top two rows A and B remained yellow, where extract and media were checked for contamination.

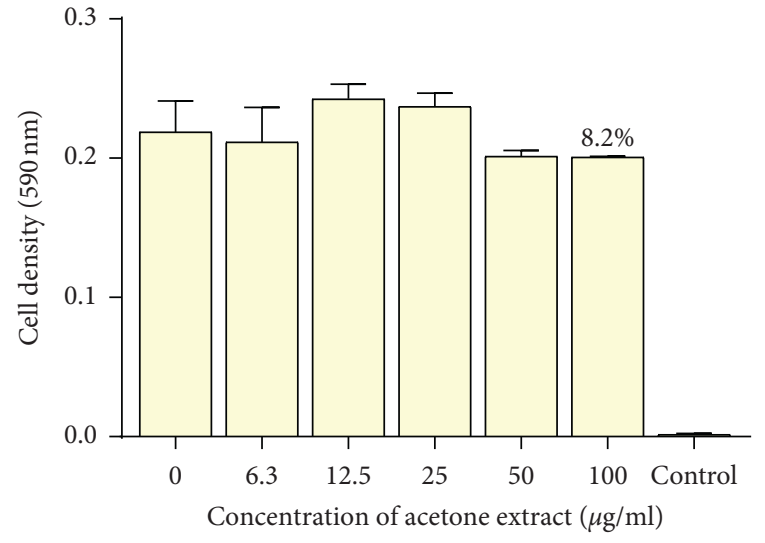

(a)

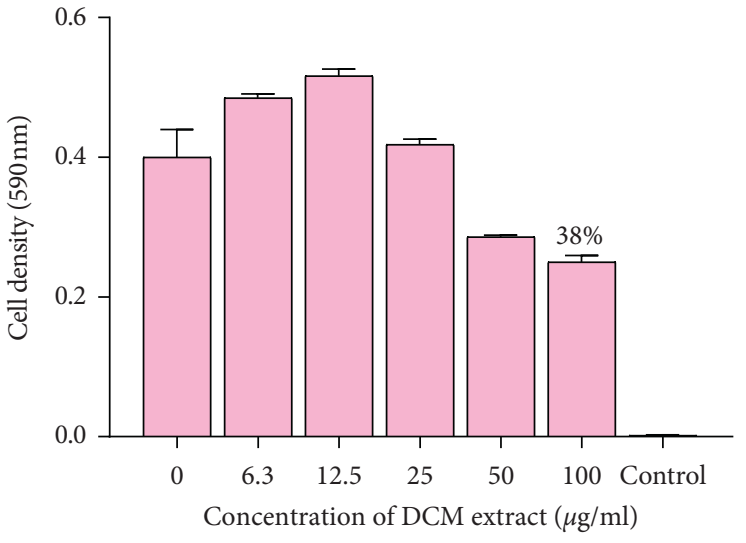

(b)

Figure 2: Continued. 


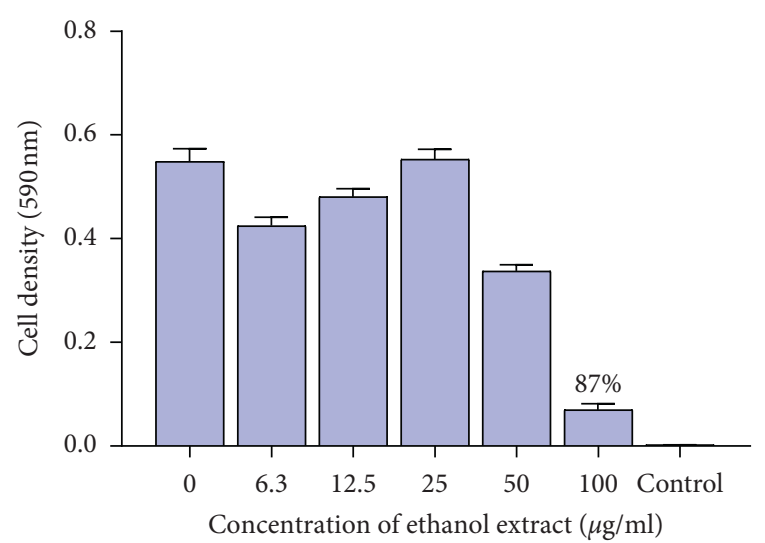

(c)

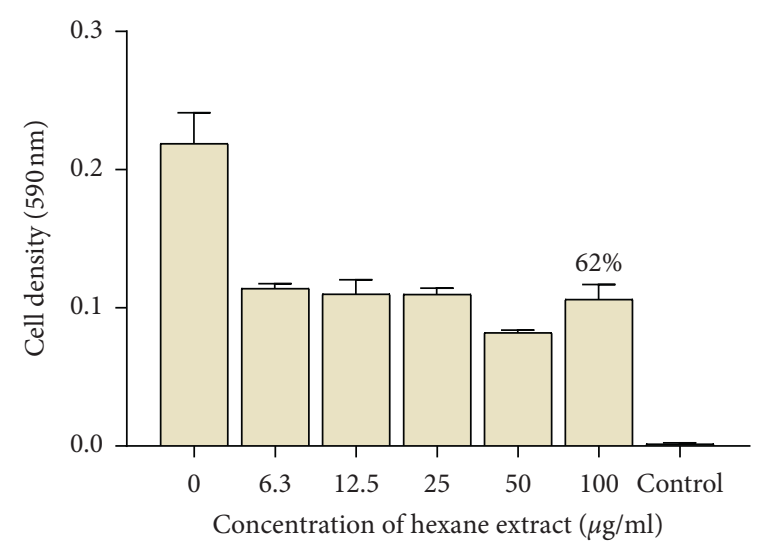

(d)

Figure 2: The effects of extracts of pods of $P$. thonningii against $M$. smegmatis: (a) effect of acetone extract, (b) effect of DCM extract, (c) effect of ethanol extract, and (d) effect of hexane extract. Concentrations of extract ranged from $6.3 \mu \mathrm{g} / \mathrm{mL}$ to $100 \mu \mathrm{g} / \mathrm{mL}$. Values are in mean cell density at $590 \mathrm{~nm}$ wavelength \pm the standard deviation; $N=4$.

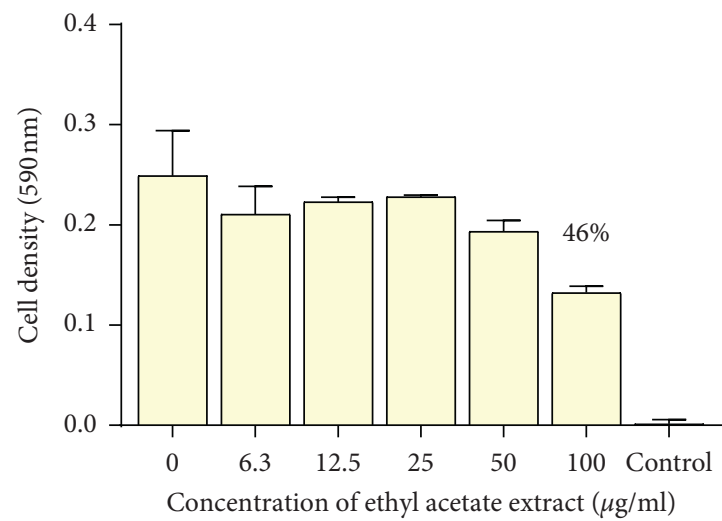

(a)

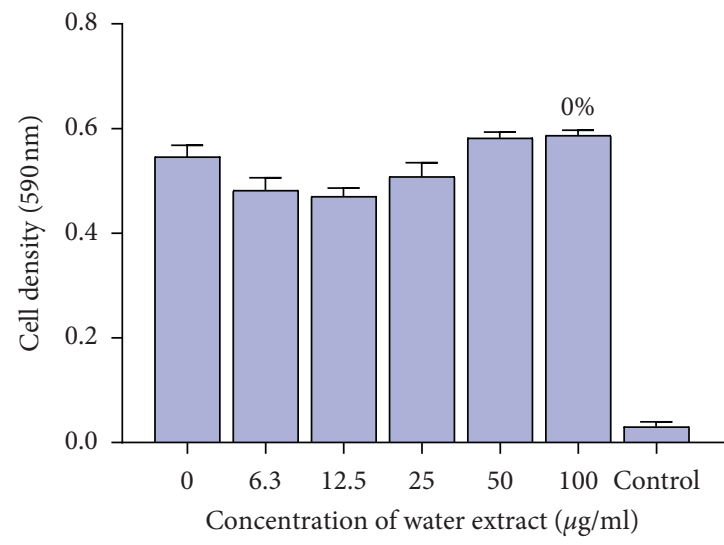

(c)

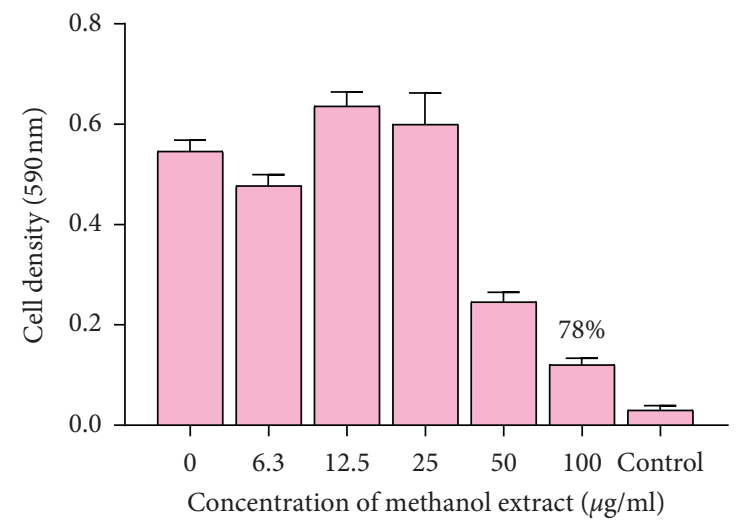

(b)

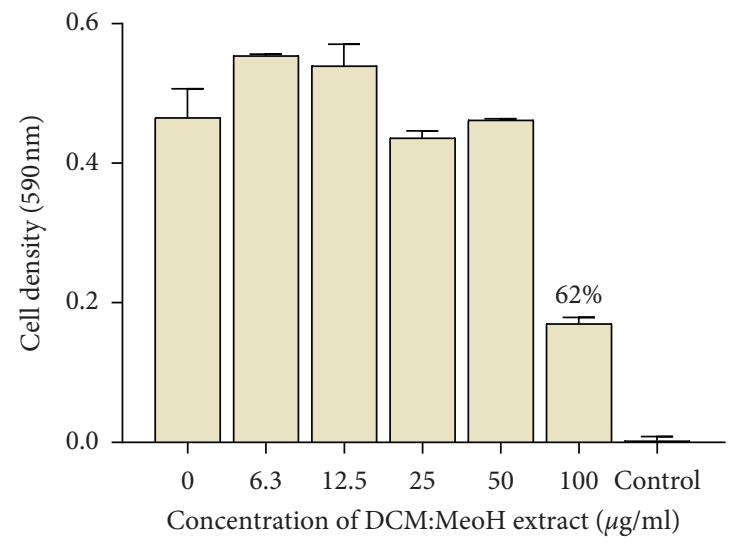

(d)

Figure 3: The effects of extracts of pods of $P$. thonningii against $M$. smegmatis: (a) effect of ethyl acetate extract, (b) effect of methanol extract, (c) effect of water extract, and (d) effect of DCM : MeOH extract. Concentrations of extract ranged from $6.3 \mu \mathrm{g} / \mathrm{mL}$ to $100 \mu \mathrm{g} / \mathrm{mL}$. Values are in mean cell density at $590 \mathrm{~nm}$ wavelength \pm the standard deviation; $N=4$. 


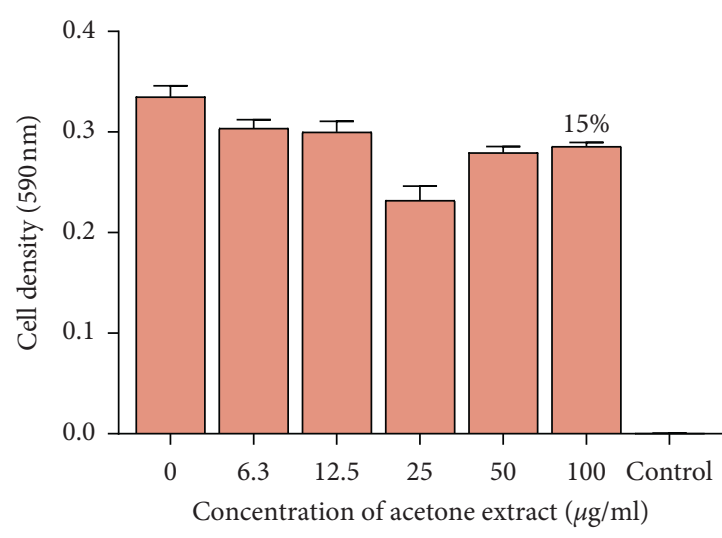

(a)

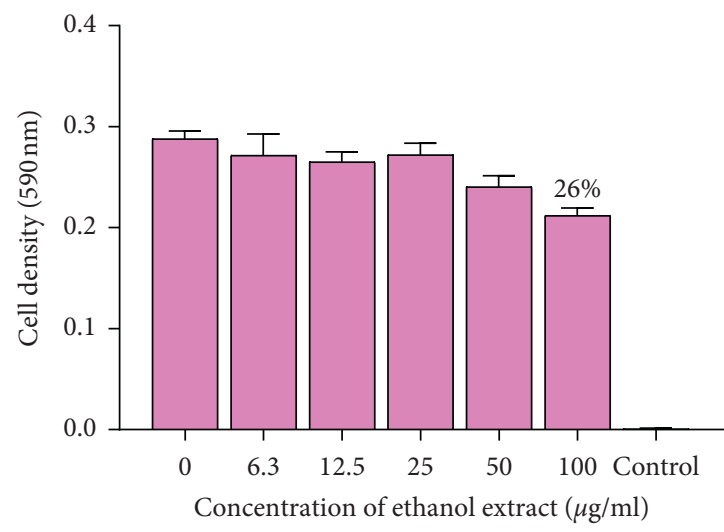

(c)

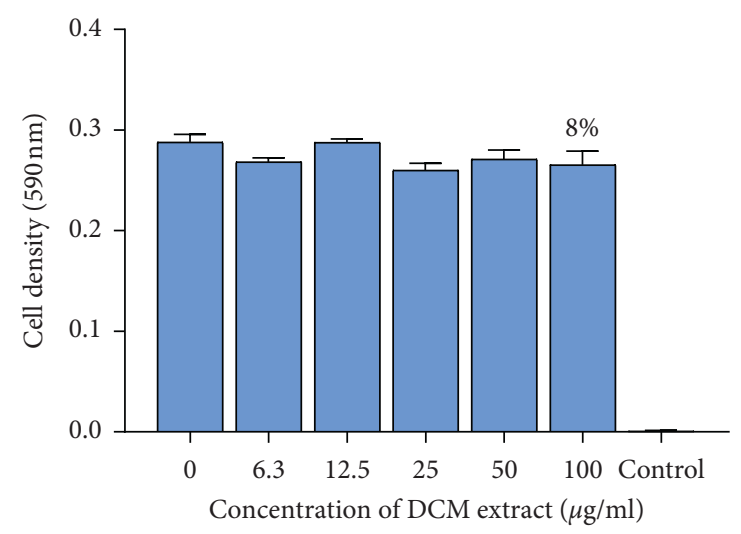

(b)

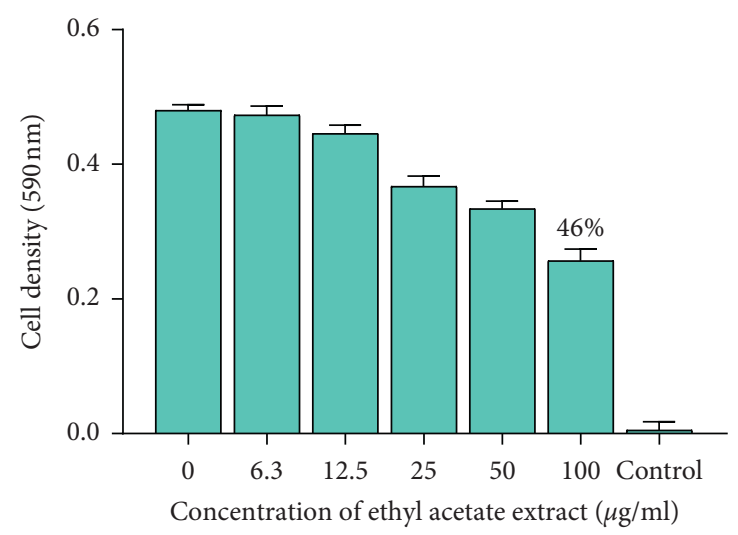

(d)

Figure 4: The effects of extracts of pods of $P$. thonningii against $P$. aeruginosa: (a) effect of acetone extract, (b) effect of DCM extract, (c) effect of ethanol extract, and (d) effect of ethyl acetate extract. Concentrations of extract ranged from $6.3 \mu \mathrm{g} / \mathrm{mL}$ to $100 \mu \mathrm{g} / \mathrm{mL}$. Values are in mean cell density at $590 \mathrm{~nm}$ wavelength \pm the standard deviation; $N=4$.

third of the world population is affected by the disease [25]. The ethanol extracts from $P$. thonningii were shown to be bacteriostatic but not bactericidal. The lack of bactericidal effects can be due to the presence of cell wall made up of mycolic acids that leads to decreased antibiotic uptake renderingthe entry of drugs difficult and leading to an increase in antibacterial resistance of TB [26]. The other extracts were shown to be less effective and these were the acetone, ethyl acetate, dichloromethane, and water extracts. Comparing with a study done by Mautsa and Mukanganyama [27], the plant Vernonia adoensis was shown to be effective against $M$. smegmatis using extracts from the leaves and flowers. It has also been reported that the leaves of $P$. thonningii have no antitubercular activity but show remarkable general antimicrobial activity against both Grampositive and Gram-negative bacteria [28].

3.1.2. The Antibacterial Effects of the Extracts against $P$. aeruginosa. The antibacterial effects assay of the 8 extracts against $P$. aeruginosa were determined. The results were plotted as graphs of cell density at $590 \mathrm{~nm}$ wavelength against the concentration of the extract shown in Figures 4 and 5. There was no MIC observed from all the 8 extracts.
The methanol extract $(100 \mu \mathrm{g} / \mathrm{mL})$ inhibited the growth of $P$. aeruginosa with a percentage inhibition of $72 \%$ followed by the exhaustive extract (methanol and dichloromethane 1 : 1 mixtures) which had a percentage inhibition of $70 \%$ at $100 \mu \mathrm{g} / \mathrm{mL}$ of the concentration of the extracts. Other extracts at $100 \mu \mathrm{g} / \mathrm{mL}$, namely, hexane, acetone, ethyl acetate, ethanol, and dichloromethane, were less effective in inhibiting the growth of $P$. aeruginosa. This was attributed to the fact that Gram-negative bacteria possess an additional outer membrane composed of hydrophilic lipopolysaccharide layer that mimics the entry of hydrophobic and amphipathic compound which encompasses many drug compounds [18].

According to the study by Njeru et al. [28], the methanol crude extracts of $P$. thonningii leaves were shown to be more effective against Gram-negative bacteria with a MIC of $12.5 \mu \mathrm{g} / \mathrm{mL}$ of the extracts. A study by Nguta et al. [29] showed that the growth of $P$. aeruginosa was inhibited by the methanol extract with a zone of inhibition between $23 \mathrm{~mm}$ and $24 \mathrm{~mm}$. A study from Akinpelu and Obuotor [2] was of interest to our investigations as it showed that the stem bark extract of $P$. thonningii exhibited no activity against $P s e u-$ domonas aeruginosa and Serratia marcescens. In this study, no MIC was observed for any of the extracts. However, 


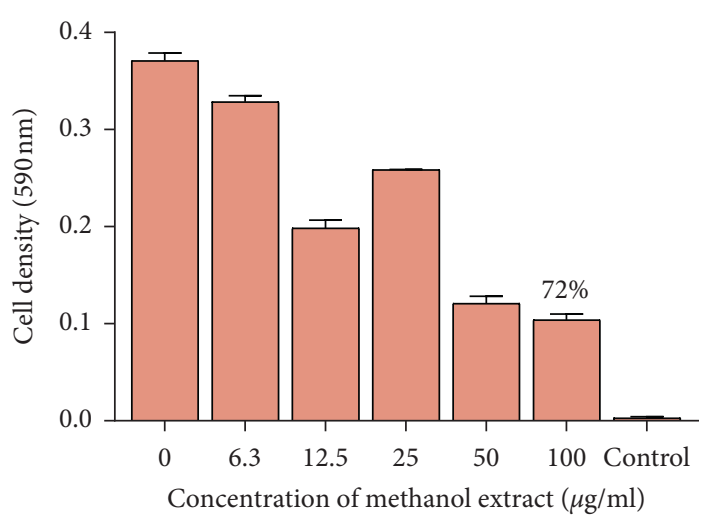

(a)

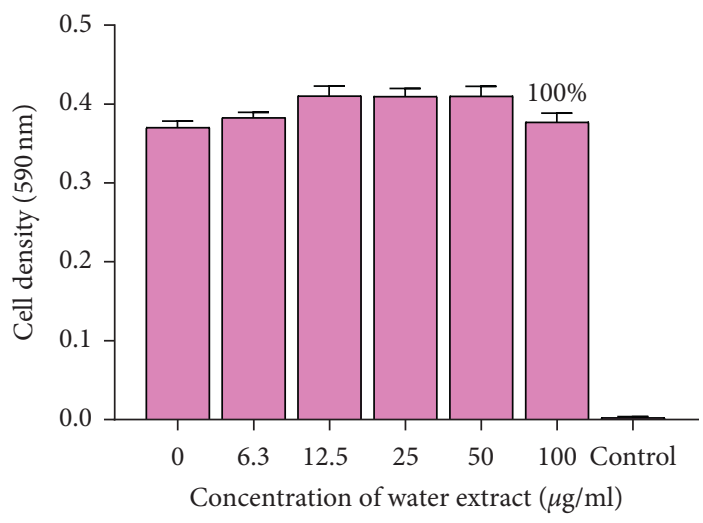

(c)

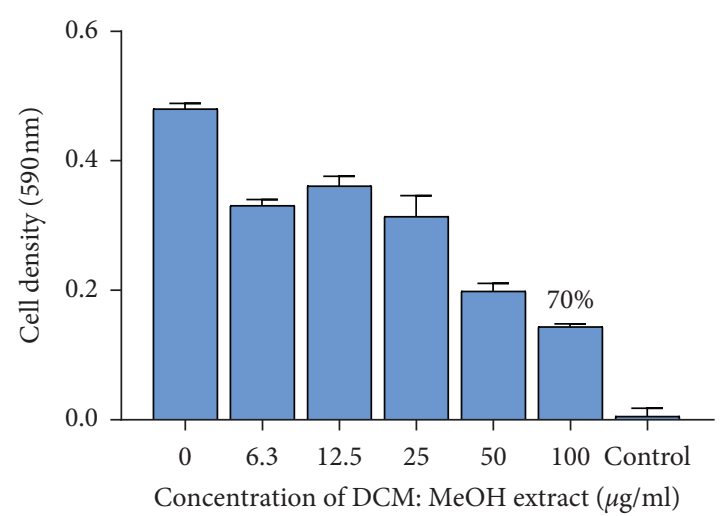

(b)

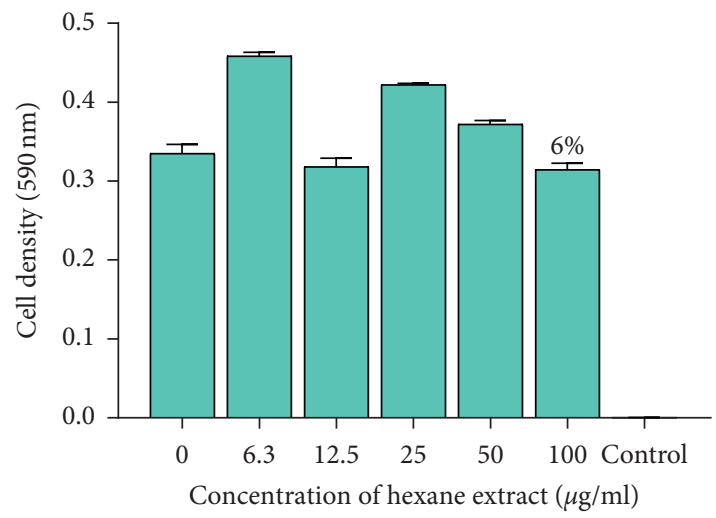

(d)

Figure 5: The effects of extracts of pods of $P$. thonningii against $P$. aeruginosa: (a) effect of methanol extract, (b) effect of DCM:MeOH extract, (c) effect of water extract, and (d) effect of hexane extract. Concentrations of extract ranged from $6.3 \mu \mathrm{g} / \mathrm{mL}$ to $100 \mu \mathrm{g} / \mathrm{mL}$. Values are in mean cell density at $590 \mathrm{~nm}$ wavelength \pm the standard deviation. $N=4$.

previous results showed that antibacterial property of the methanol extracts from different parts of plants can exhibit highly significant variations in the pattern of inhibition [30-32] even with no observable MIC. Our findings are in agreement with those found by Mostafa et al. [32] who found that extracts of Rumex vesicarius L. seeds have variable effects against both Gram-positive bacteria and Gramnegative bacteria. The presence of antibacterial property of the methanol extract $P$. thonningii corresponds to the report by Jimoh and Oladiji [33] and Daniyan et al. [34] that attributed the presence of flavonoids in the seeds and stem extracts of $P$. thonningii for its antimicrobial activity. Our results are in line with those reported by Ighodaro et al. [14] on the microbial activities of $P$. thonningii against one of the most important human pathogenic bacterium. Antibacterial activity studies by Dluya et al. [35] also reported that the methanol extract from $P$. thonningii showed activity on five selected pathogenic organisms at varied concentrations of the extract. The antibacterial activities of $P$. thonningii fruit methanol extract can be attributed to the presence of metabolic toxins as well as broad spectrum antimicrobial compounds that may act against bacteria. In another study by Dluya and Dahiru [36], it was shown that the methanol stem bark extract of $P$. thonningii significantly inhibited the growth of S. aureus, S. typhi, and P. aeruginosa.
3.1.3. The Antifungal Effects of the Extracts against C. krusei. The antifungal assay of the 8 extracts of the pods of $P$. thonningii against $C$. krusei was determined. The results were plotted as graphs of cell density at $590 \mathrm{~nm}$ against the concentration of the extracts as shown in Figures 6 and 7. The results show that ethanol extract $(100 \mu \mathrm{g} / \mathrm{mL})$ had the highest percentage growth inhibition of $90 \%$, whilst extracts such as water showed no activity. There was no MIC observed for the concentration of all the extracts used. Other extracts at $100 \mu \mathrm{g} / \mathrm{mL}$ showed moderate growth inhibition of $16 \%, 27 \%, 36 \%$, and $24 \%$ for extracts acetone, DCM: $\mathrm{MeOH}$, methanol, and hexane extracts, respectively.

ofAstudy on the effect of grape seedextracts revealed that at $50 \mu \mathrm{g} / \mathrm{mL}$ ofthe extract, there was inhibition of the growth of C. krusei [37]. The antifungal activity of P. thonningii against $C$. albicans was studied previously with the ethanolic extract showing significant activity in inhibiting the growth of cells and an MIC of $0.312 \mu \mathrm{g} / \mathrm{mL}$. Other studies [38,39] have found that the ethanol leaf extract of Cassia alata caused a dose-dependent effect on Candida albicans, Microsporum canis, and Trichophyton mentagrophyte. The phytochemical and antifungal analysis of the ethanolic extract of $P$. thonningii showed the presence of flavonoids which were effective in inhibiting the growth of C. albicans, Colletotrichum musae, and Sclerotium rolfsii [40-42]. 


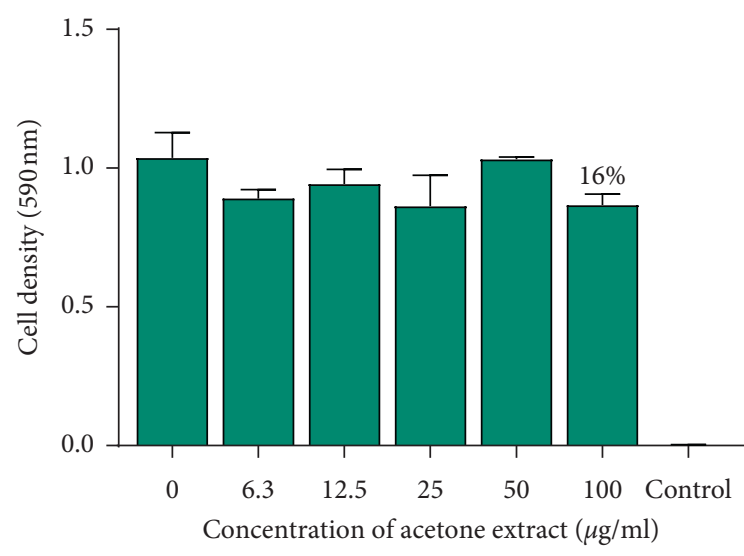

(a)

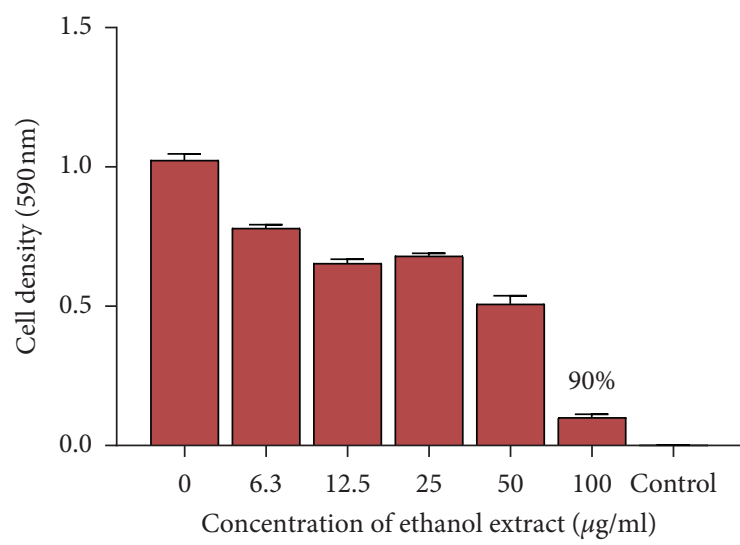

(c)

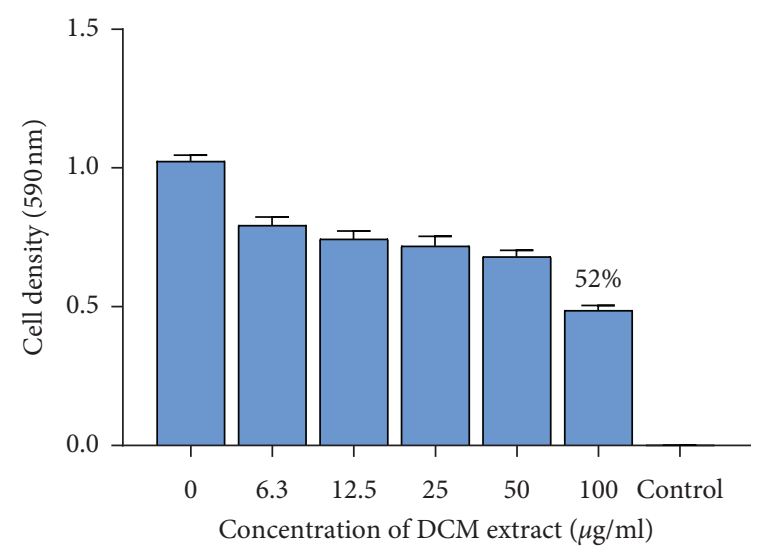

(b)

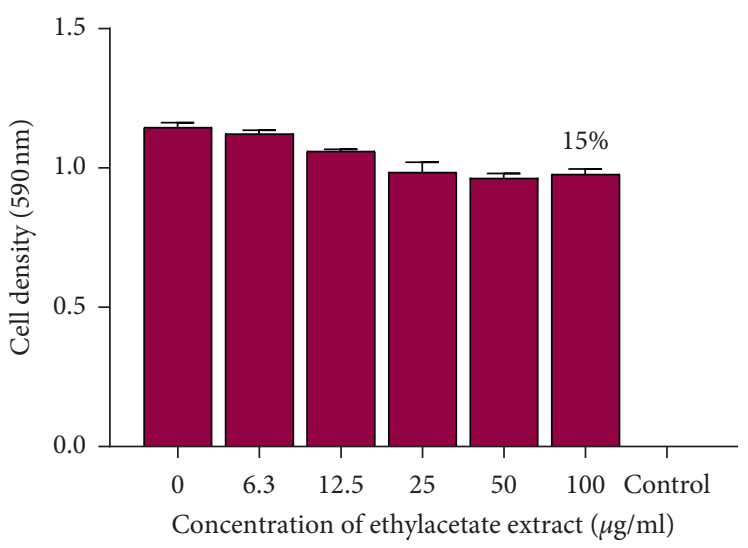

(d)

Figure 6: The effects of extracts of pods of $P$. thonningii against C. krusei: (a) effect of acetone extract, (b) effect of DCM extract, (c) effect of the ethanol extract, and (d) effect of ethyl acetate extract. Concentrations of extract ranged from $6.3 \mu \mathrm{g} / \mathrm{mL}$ to $100 \mu \mathrm{g} / \mathrm{mL}$. Values are in mean cell density at $590 \mathrm{~nm}$ wavelength \pm the standard deviation. $N=4$.

Therefore, plants and herbal compounds used in the traditional treatment of diseases including fungal infections are potential sources for the development of new antifungal agents [43]. The moderate activity of some crude extracts can be attributed to the fact that C. krusei has developed resistance to several drugs especially to the group of azoles that target the cell wall structure of the fungal [44]. The ability of the ethanol extract to inhibit the growth of tested organism indicates antifungal potential that may be used in the treatment of fungal infections [40].

3.1.4. Effect of the Extracts on the Membrane Integrity. The most potent extracts were further used to determine the possible mode of action of the extracts by determining the effects of protein leakages from the microorganisms. The most potent extract was the ethanol extract and, thus, it was tested on all the three species. The extracts concentration used was $50 \mu \mathrm{g} / \mathrm{mL}, 100 \mu \mathrm{g} / \mathrm{mL}$, and $200 \mu \mathrm{g} / \mathrm{mL}$. The positive control includes ampicillin, $0.1 \%$ SDS and miconazole for $M$. smegmatis, C. krusei, and $P$. aeruginosa, respectively. The protein concentration values were interpolated from the standard curve using GraphPad Prism version 5.03. The results showed that as the concentration of the ethanol extract was increased, there was significant leakage of protein from the three species (Figure 8). There was more protein leakage in $P$. aeruginosa exposed to $200 \mu \mathrm{g} / \mathrm{mL}$ concentration of the extract giving a leakage of $4 \mu \mathrm{g} / \mathrm{mL}$ of protein.

It was also shown that the ethanol extract caused membrane leakage in C. krusei and M. smegmatis. With increasing concentration of the extracts, the amount of protein that leaked also increases. In a study by Mautsa and Mukanganyama [27], exposure of M. smegmatis to leaf extracts from Vernonia adoensis caused leakage of proteins, and it was suggested that the extracts bind to the lipids and polysaccharides on the membrane leading to membrane disruption. The polar solvent extracts of six plant species have shown higher antimicrobial activity against multidrugresistant strains of Mycobacterium smegmatis [45]. This has been attributed to the fact that ethanol, as the extractant, has high concentration of diterpenoids potentially contributing to the antimycobacterial activity observed in this study [46-48]. The antimycobacterial activity was carried, out and it was found that the ethanol extract affected the growth of M. smegmatis for P. americana, Artemisia afra, Dodonaea angustifolia, Drosera capensis, and Galenia africana [49-51]. 


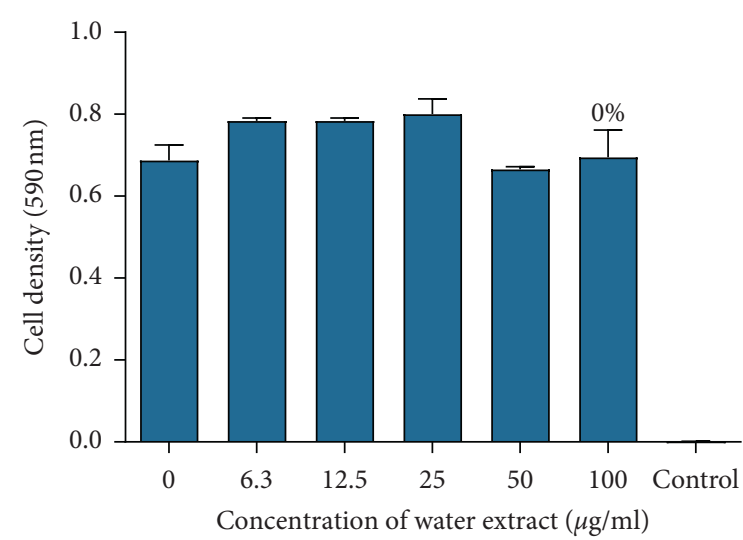

(a)

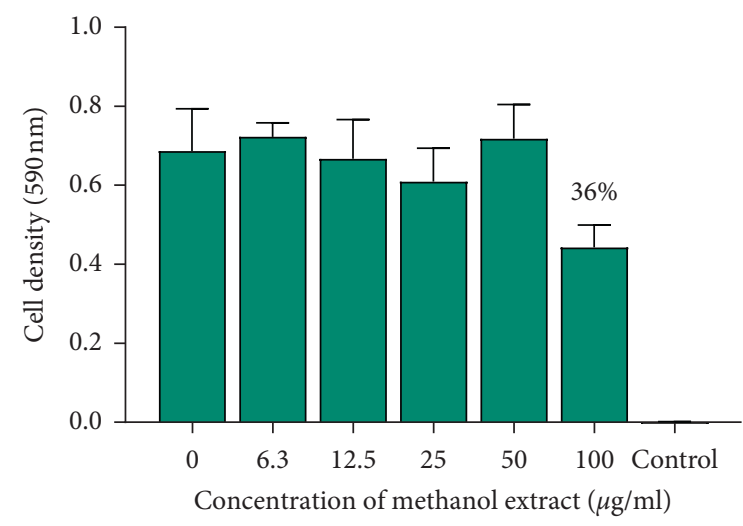

(c)

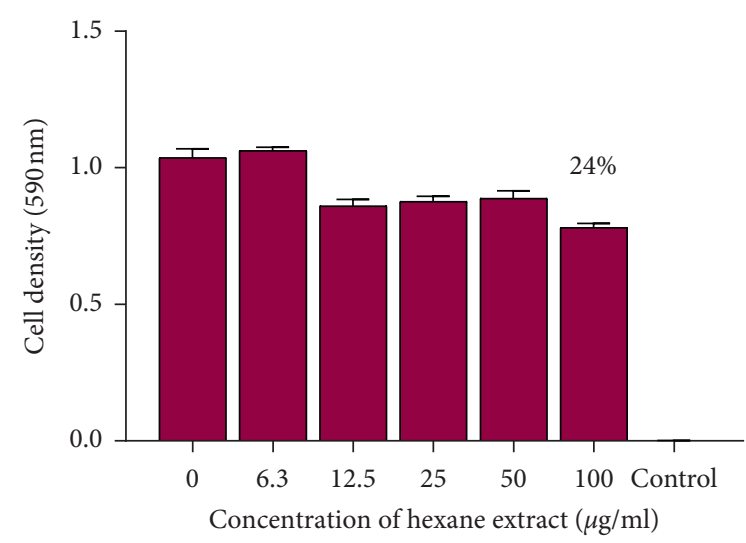

(b)

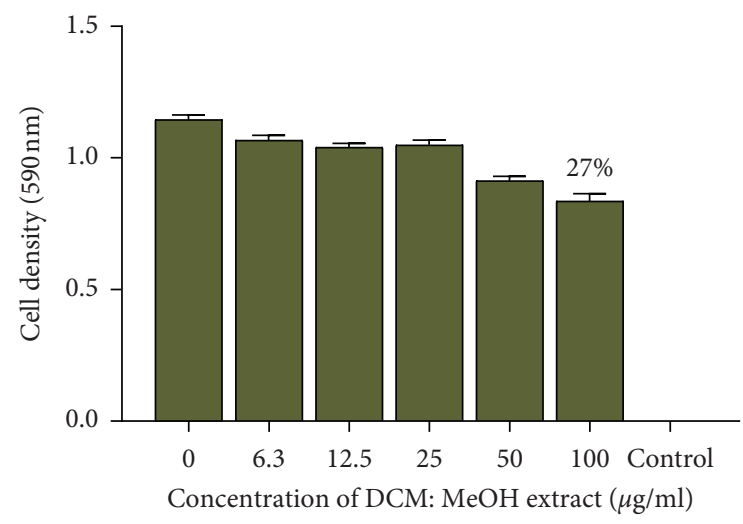

(d)

Figure 7: The effects of extracts of pods of $P$. thonningii against C. krusei: (a) effect of water extract, (b) effect of hexane extract, (c) effect of the methanol extract, and (d) effect of ethyl acetate extract. Concentrations of extract ranged from $6.3 \mu \mathrm{g} / \mathrm{mL}$ to $100 \mu \mathrm{g} / \mathrm{mL}$. Values are in mean cell density at $590 \mathrm{~nm}$ wavelength \pm the standard deviation. $N=4$.

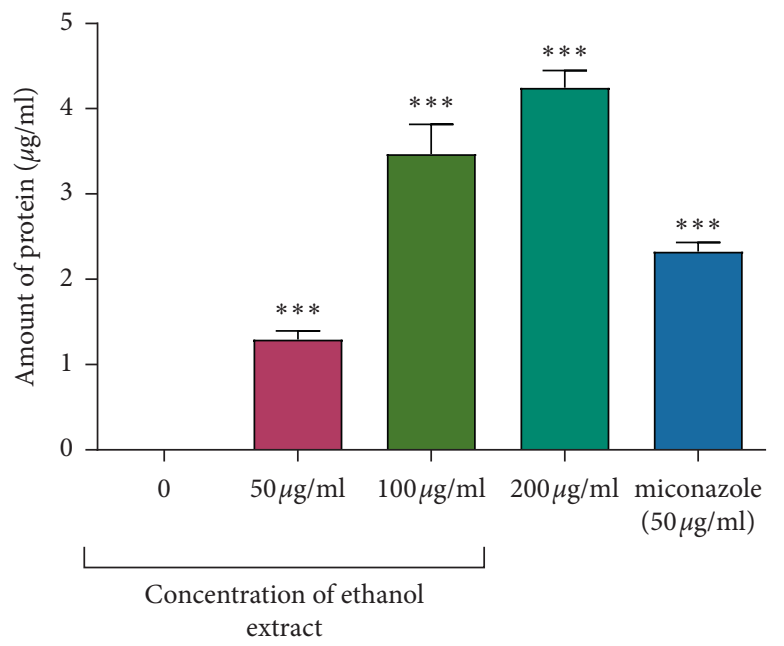

(a)

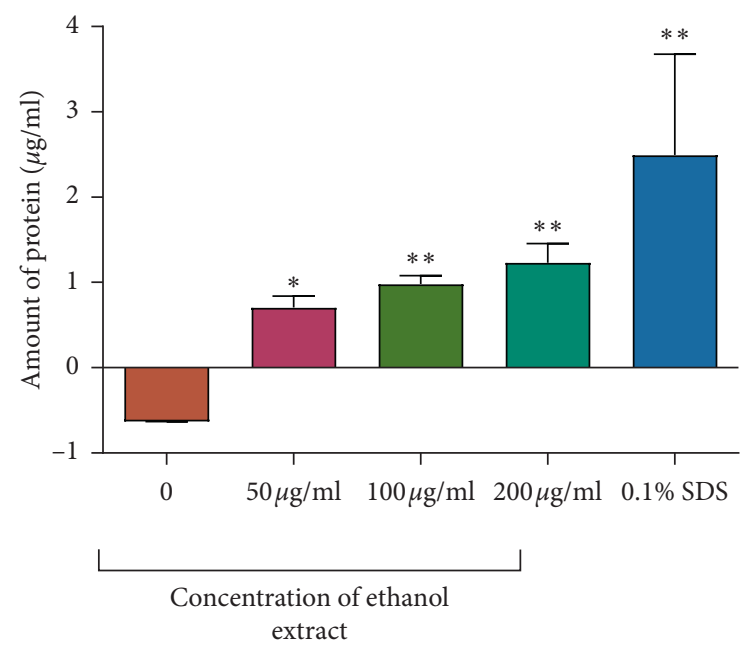

(b)

FIgUre 8: Continued. 


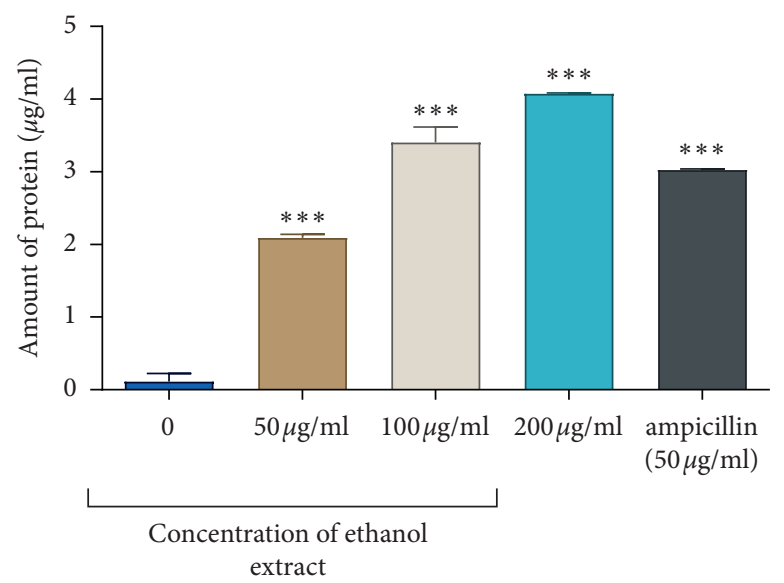

(c)

Figure 8: The effects of the ethanol crude on protein leakage in C. krusei, M. smegmatis, and P. aeruginosa. The results show the protein leakage assay for the effect of $P$. thonningii extract on C. krusei (a), M. smegmatis (b), and P. aeruginosa (c). The assay was carried out at varying concentrations of both the drug and extract. The positive control for C. krusei was miconazole, for M. smegmatis was $0.1 \%$ SDS, and for $P$. aeruginosa was ampicillin. ${ }^{*} P<0.05,{ }^{* *} P<0.001$, and ${ }^{* * *} P<0.0001$.

These studies provide a scientific basis of our results that the ethanol extract of $P$. thonningii fruits can be used in local medicinal applications by traditional practitioners. Membrane integrity maintains $\mathrm{pH}$, ATP production, and membrane potential and integrity for the physiological functions. The perturbation of the homeostasis of these biochemical molecules can form the basis action of novel antimicrobial agents [52]. Due to the development of mycobacterial persisters as well as antimycobacterial resistance, alternative treatment regimens are urgently required. The disruption of the bacterial membrane by chemical agents has emerged as an effective means to eradicate or inhibit the growth of bacteria, thereby, allowing the treatment and reduction of infectious diseases [53]. Most antifungal agents have been developed to primarily inhibit enzymes that are involved in the biosynthesis of the fungal cell membrane components such as phospholipid, sphingolipid, and ergosterol [54].

\section{Conclusion}

Antimicrobial activity was observed from extracts from the pods of $P$. thonningii. The most effective extract was ethanol extract with the $100 \mu \mathrm{g} / \mathrm{mL}$ concentration inhibiting the growth of cells to $26 \%, 87 \%$, and $90 \%$ for $P$. aeruginosa, M. smegmatis, and C. krusei, respectively. The possible mode of action of the ethanol extracts could be disruption of membrane integrity of bacteria, mycobacteria, and fungi since there was significant leakage of proteins from these microorganisms. The pods of $P$. thonningii have shown to have antimicrobial activity with membrane damaging effects on microbes. Further work on isolation and pontification of the phytochemicals from the pods is warranted.

\section{Data Availability}

The datasets used and/or analysed during the current study are available from the corresponding author on reasonable request.

\section{Conflicts of Interest}

The authors declare that they have no conflicts of interest.

\section{Acknowledgments}

The authors acknowledge the assistance of Christopher Chapano of the National Herbarium and Botanical Gardens (Harare, Zimbabwe) for authentication of the identity of the plant species. Support from the Swedish International Development Agency (SIDA) through the International Science Programmes (ISP) (IPICS: ZIM01, Uppsala University, Uppsala, Sweden) is acknowledged. ISP IPICS: ZIM01 supported the research under the title "Biomolecular Interactions Analyses." Support from the Alliance for Global Health and Science (University of California, Berkeley) is also acknowledged.

\section{References}

[1] D. J. Newman and G. M. Cragg, "Natural products as sources of new drugs over the nearly four decades from 01/1981 to 09/ 2019," Journal of Natural Products, vol. 83, no. 3, pp. 770-803, 2020.

[2] D. A. Akinpelu and E. M. Obuotor, "Antibacterial activity of Piliostigma thonningii stem bark," Fitoterapia, vol. 71, no. 4, pp. 442-443, 2000.

[3] A. Maroyi, "Traditional use of medicinal plants in southcentral Zimbabwe: review and perspectives," Journal of Ethnobiology and Ethnomedicine, vol. 9, no. 1, p. 31, 2013. 
[4] M. Asadi-Samani, W. Kooti, E. Aslani, and H. Shirzad, "A systematic review of Iran's medicinal plants with anticancer effects," Journal of Evidence-Based Complementary \& Alternative Medicine, vol. 21, no. 2, pp. 143-153, 2016.

[5] T. K. Mahato and K. Sharma, "Study of medicinal herbs and its antibacterial activity: a review," Journal of Drug Delivery and Therapeutics, vol. 8, no. 5, pp. 47-54, 2018.

[6] F. Jamshidi-Kia, Z. Lorigooini, and H. Amini-Khoei, "Medicinal plants: past history and future perspective," Journal of Herbmed Pharmacology, vol. 7, no. 1, pp. 1-7, 2018.

[7] S. T. Mahwasane, L. Middleton, and N. Boaduo, "An ethnobotanical survey of indigenous knowledge on medicinal plants used by the traditional healers of the Lwamondo area, Limpopo province, South Africa," South African Journal of Botany, vol. 88, pp. 69-75, 2013.

[8] J. E. Burrows, S. M. Burrows, M. C. Lötter, and E. Schmidt, Trees and Shrubs Mozambique Publishing Print Matters (PTY), Includes a picture, Cape Town, South Africa, 2018.

[9] M. Afolayan, R. Srivedavyasasri, O. T. Asekun et al., "Phytochemical study of Piliostigma thonningii, a medicinal plant grown in Nigeria," Medicinal Chemistry Research, vol. 27, no. 10, pp. 2325-2330, 2018.

[10] K. Dasofunjo, O. F. C. Nwodo, O. E. Yakubu et al., "Toxicological implication of ethanol leaf extract of Piliostigma thonningii on renal function indices of male wistar albino rats," European Journal of Experimental Biology, vol. 3, no. 3, pp. 652-655, 2013.

[11] I. Igbe, J. E. Chukwuenweniwe, A. Peter, and Q. E. Osazuwa, "Analgesic and antiinflammatroy activity of the aqueous leaf extract of Piliostigma thonningii (Caesalpinoideae)," Journal of Pharmaceutical Bioresourses, vol. 9, no. 1, pp. 34-38, 2012.

[12] B. Olela, J. Mbaria, T. Wachira, and G. Moriasi, "Acute oral toxicity and anti-inflammatory and analgesic effects of aqueous and methanolic stem bark extracts of Piliostigma thonningii (Schumach.)," Evidence-Based Complementary and Alternative Medicine, vol. 2020, Article ID 5651390, 10 pages, 2020.

[13] E. K. Ouattara, K. Coulibaly, T. D. Etien, and N. G. Zirihi, "Etude ethnobotanique de plantes antifongiques utilisées traditionnellement en Côte d'Ivoire et du potentiel de," International Journal of Biological and Chemical Sciences, vol. 14, no. 1, pp. 239-253, 2020.

[14] O. M. Ighodaro, S. O. Agunbiade, J. O. Omole, and O. A. Kuti, "Evaluation of the chemical, nutritional, antimicrobial and antioxidant-vitamin profiles of Piliostigma thonningii leaves," Research Journal of Medicinal Plant, vol. 6, no. 7, pp. 537-543, 2012.

[15] G. A. Moriasi, A. M. Ireri, and M. P. Ngugi, "In vivo cognitiveenhancing, Ex vivo malondialdehyde-lowering activities and phytochemical profiles of aqueous and methanolic stem bark extracts of Piliostigma thonningii (schum.)," International Journal of Alzheimer's Disease, vol. 2020, Article ID 1367075, 15 pages, 2020.

[16] A. Mohanty, S. Meena, K. N. Uttam, V. Sudeep, and N. Kaistha, "Candida krusei infection in an acute lymphocytic leukaemia patient: a case report," Journal of Clinical \& Diagnostic Research, vol. 14, no. 5, 2020.

[17] S. B. Snapper, R. E. Melton, S. Mustafa, T. Kieser, and W. R. Jacobs Jr., "Isolation and characterization of efficient plasmid transformation mutants of Mycobacterium smegmatis," Molecular Microbiology, vol. 4, no. 11, pp. 1911-1919, 1990.

[18] K. Streeter and M. Katouli, "Pseudomonas aeruginosa: a review of their pathogenesis and prevalence in clinical settings and the environment," pp. 25-32, 2016.
[19] M. Ahmad and M. Wajid, "Plants as potential source of antimicrobial agents," Journal of Pharmaceutical and Alternative Medicine, vol. 2, pp. 18-25, 2013.

[20] D. Amenu, "Antimicrobial activity of medicinal plant extracts and their synergistic effect on some selected pathogens," American Journal of Ethnomedicine, vol. 1, no. 1, pp. 18-29, 2014.

[21] E. Fouda, E. N. Ayman, M. Alaa, A. H. Enas, O. Gamal, and M. Farid, "Early detection of anastomotic leakage after elective low anterior resection," Journal of Gastrointestinal Surgery, vol. 15, no. 1, pp. 137-144, 2011.

[22] Y. Chen, H. Yuping, Z. Weiping et al., "Pathogenic characteristics of nosocomial infections in patients with cerebrovascular diseases and characteristics and treatment of pathogenic bacteria in different seasons," Journal of Infection and Public Health, vol. 13, no. 5, pp. 800-805, 2020.

[23] H. Y. Kato Yoshimura, S. Yoshihiro, S. Hiroyuki et al., "Mortality and risk factor analysis for Candida blood stream infection: a multicenter study," Journal of Infection and Chemotherapy, vol. 25, no. 5, pp. 341-345, 2019.

[24] N. Lelovic, K. Mitachi, Y. Junshu, M. R. Lemieux, J. Yinduo, and M. Kurosu, "Application of Mycobacterium smegmatis as a surrogate to evaluate drug leads against Mycobacterium tuberculosis," The Journal of Antibiotics, vol. 73, pp. 1-10, 2020.

[25] D. Quan, N. Gayathri, R. Payne, and J. A. Triccas, "New tuberculosis drug leads from naturally occurring compounds," International Journal of Infectious Diseases, vol. 56, pp. 212-220, 2017.

[26] L. Fernández, J. B. McPhee, T. Sandeep, M. D. Brazas, S. Lewenza, and R. E. W. Hancock, "Antibiotic resistance due to reduced uptake," in Antimicrobial Drug Resistance, pp. 115-130, Springer, Cham, Switzerland, 2017.

[27] R. Mautsa and S. Mukanganyama, "Vernonia adoensis leaf extracts cause cellular membrane disruption and nucleic acid leakage in Mycobacterium smegmatis," Journal of Biologically Active Products from Nature, vol. 7, no. 2, pp. 140-156, 2017.

[28] S. N. Njeru, M. A. Obonyo, S. M. Ngari, S. N. Onsarigo, J. M. Njeru, and P. K. Kamweru, "Antituberculous, antimicrobial, cytotoxicity and phytochemical activity study of Piliostigma thonningii extract fractions," Journal of Medicinal Plants Research, vol. 9, no. 22, pp. 655-663, 2015.

[29] J. M. Nguta, J. M. Mbaria, and W. D. Mvula, "Brine shrimp toxicity and in vitro antimicrobial activity of Piliostigma thonningii (Schum.) Milne-Redh.[Leguminosae-Caesalpinioideae] from Kenya and Malawi against some pathogens of human and veterinary importance," Journal of Veterinary Medicine and Animal Health, vol. 5, no. 9, pp. 251-256, 2013.

[30] P. Verma and A. Verma, "Evaluation of antibacterial activity of different parts of Tagetes erecta," International Journal of Pharmacy and Life Sciences, vol. 3, no. 6, pp. 1766-1768, 2012.

[31] S. Li, X. Cheng, and C. Wang, "A review on traditional uses, phytochemistry, pharmacology, pharmacokinetics and toxicology of the genus Peganum," Journal of Ethnopharmacology, vol. 203, pp. 127-162, 2017.

[32] H. A. M. Mostafa, A. A. Elbakry, and A. A. Eman, "Evaluation of antibacterial and antioxidant activities of different plant parts of Rumex vesicarius L. (Polygonaceae)," International Journal of Pharmacy and Pharmaceutical Sciences, vol. 3, no. 2, pp. 109-118, 2011.

[33] F. O. Jimoh and A. T. Oladiji, "Preliminary studies on Piliostigma thonningii seeds: proximate analysis, mineral 
composition and phytochemical screening," African Journal of Biotechnology, vol. 4, no. 12, pp. 1439-1442, 2005.

[34] S. Y. Daniyan, M. Galadima, U. J. J. Ijah, L. E. Odama, A. Y. Yusuf, and Y. Abbas, "In vitro antibacterial screening of Piliostigma thonningii (schum) Milne red head leaves extracts against clinical isolates of methicillin resistant and methicillin sensitive Staphylococcus aureus," International Journal of Pure and Applied Sciences, vol. 4, no. 1, pp. 88-94, 2010.

[35] T. Dluya, D. Dahiru, and Y. W. Gaiuson, "Comparative biochemical evaluation of leaf extracts of Ficus sycomorus and Piliostigma thonningii plant," Journal of Medicinal Plants Studies, vol. 3, pp. 32-37, 2015.

[36] T. Dluya and D. Dahiru, "Antibacterial activity of Piliostigma Thonningii methanol stem bark extract," International Journal of Research in Pharmacy and Biosciences, vol. 5, pp. 15-20, 2018.

[37] H. Eslami, H. Babaei, S. P. Mehrbani, A. Marzieh, B. Zahra, and S. K. Nezhad, "Evaluation of antifungal effect of grape seed extract (GSE) on Candida glabrata and Candida krusei: in vitro study," Biomedical Research (India), vol. 28, no. 21, pp. 9163-9170, 2017.

[38] A. Agban, K. A. Gbogbo, P. H. Yao et al., "Évaluation de l'activité antifongique des extraits de Cassia alata L. et de Piliostigma thonningii (Schumach.) Milne Redh.(Fabaceae) sur Candida albicans," International Journal of Biological and Chemical Sciences, vol. 7, no. 3, pp. 1041-1047, 2013.

[39] S. Fatmawati, A. S. Purnomo, and M. F. A. Bakar, "Chemical constituents, usage and pharmacological activity of Cassia alata," Heliyon, vol. 6, no. 7, Article ID e04396, 2020.

[40] S. S. Ipav, K. Dasofunjo, T. T. Sar, and C. E. Hilary, "Antimicrobial and bioactive potentials of extracts of Piliostigma thonningii leaves," Nigerian Annals of Pure and Applied Sciences, vol. 6, pp. 22-27, 2015.

[41] E. K. Ouattara, K. Coulibaly, D. E. Théodore, and N. G. Zirihi, "Etude ethnobotanique de plantes antifongiques utilisées traditionnellement en Côte d'Ivoire et du potentiel de Piliostigma Thonningii (schumach.) milneredh.(Fabaceae) dans le contrôle de souches telluriques," International Journal of Biological and Chemical Sciences, vol. 14, no. 1, pp. 239-253, 2020.

[42] O. J. Babajide, O. O. Babajide, A. O. Daramola, and W. T. Mabusela, "Flavonols and an oxychromonol from Piliostigma reticulatum," Phytochemistry, vol. 69, no. 11, pp. 2245-2250, 2008.

[43] L. Kokoska, P. Kloucek, L. Olga, and P. Novy, "Plant-derived products as antibacterial and antifungal agents in human health care," Current Medicinal Chemistry, vol. 26, no. 29, pp. 5501-5541, 2019.

[44] R. D. Cannon, E. Lamping, A. R. Holmes et al., "Effluxmediated antifungal drug resistance," Clinical Microbiology Reviews, vol. 22, no. 2, pp. 291-321, 2009.

[45] I. Ahmad, A. M. Mushtaq, S. Saurabh et al., "Phytochemical screening and in-vitro antibacterial and anticancer activity of crude extract of Matricaria aurea," Current Pharmaceutical Design, vol. 26, 2020.

[46] C. B. Oosthuizen, N. Gasa, C. J. Hamilton, and N. Lall, "Inhibition of mycothione disulphide reductase and mycobacterial biofilm by selected South African plants," South African Journal of Botany, vol. 120, pp. 291-297, 2019.

[47] P. Agrawal, D. Kotagiri, and V. C. Kolluru, "Comparative analysis of antimicrobial activity of herbal extracts against pathogenic microbes," Advances in Biochemistry and Biotechnology, vol. 10, pp. 2574-2578, 2018.
[48] J. R. Bame, T. N. Graf, A. J. Hiyas et al., "Sarothrin from Alkanna orientalis is an antimicrobial agent and efflux pump inhibitor," Planta Medica, vol. 79, no. 5, p. 327, 2013.

[49] A. Jiménez-Arellanes, J. Luna-Herrera, R. Ruiz-Nicolás, J. Cornejo-Garrido, A. Tapia, and L. Yépez-Mulia, "Antiprotozoal and antimycobacterial activities of Persea americana seeds," BMC Complementary and Alternative Medicine, vol. 13, no. 1, pp. 1-5, 2013.

[50] S. P. N. Mativandlela, J. J. M. Meyer, P. J. Houghton, C. J. Hamilton, and N. Lall, "Activity against Mycobacterium smegmatis and M. tuberculosis by extract of South African medicinal plants," Phytotherapy Research: An International Journal Devoted to Pharmacological and Toxicological Evaluation of Natural Product Derivatives, vol. 22, no. 6, pp. 841-845, 2008.

[51] V. F. D. Donfack, S. Roque, G. Trigo et al., "Antimycobacterial activity of selected medicinal plants extracts from Cameroon," International Journal of Biological and Chemical Sciences, vol. 8, no. 1, pp. 273-288, 2014.

[52] E. Sánchez, S. García, and N. Heredia, "Extracts of edible and medicinal plants damage membranes of Vibrio cholerae," Applied and Environmental Microbiology, vol. 76, no. 20, pp. 6888-6894, 2010.

[53] H. Chen, S. A. Nyantakyi, M. Li et al., "The mycobacterial membrane: a novel target space for anti-tubercular drugs," Frontiers in Microbiology, vol. 9, p. 1627, 2018.

[54] D. G. Sant, S. G. Tupe, C. V. Ramana, and M. V. Deshpande, "Fungal cell membrane-promising drug target for antifungal therapy," Journal of Applied Microbiology, vol. 121, no. 6, pp. 1498-1510, 2016. 